\title{
Surface mass and energy balance of Sørbreen, Jan Mayen, 2008
}

\author{
John HULTH, Cecilie ROLSTAD, Karoline TRONDSEN, Ragnhild WEDØE RØDBY \\ Department of Mathematical Sciences and Technology, Norwegian University of Life Sciences, PO Box 5003, \\ NO-1432 As, Norway \\ E-mail: john.hulth@umb.no
}

\begin{abstract}
Mass-balance measurements were initiated in 2007/08 on Sørbreen, Jan Mayen, including operation of automatic weather stations in the ablation zone. Mean daily melt rate is $3.6 \mathrm{~cm} \mathrm{w.e.} \mathrm{d}^{-1}$ for the investigated snow-free period of $\mathbf{1 1 5}$ days in June-September 2008. During this period, the net radiation is the largest contributor to melt. However, the relative contribution is highest in June $(81 \%)$ and less in September $(21 \%)$. The net longwave radiation is negative, acting as a heat sink. The climate on Jan Mayen is polar maritime with generally high humidity and overcast conditions. This leads to a positive latent heat flux, which represents condensation to the glacier surface. Persistent temperature inversions on the island lead to non-linear lapse rates and an ablation profile where melt does not necessarily decrease with increased elevation. A comparison of air temperatures on the glacier and twice-daily radiosonde ascents from the meteorological station, $\sim 20 \mathrm{~km}$ away from the glacier, shows that air temperatures at corresponding elevations are highly correlated $\left(R^{2}=0.94-0.96\right)$. This indicates that radiosonde temperature profiles can be valuable for determining lapse rates for melt modeling of the glacier.
\end{abstract}

\section{INTRODUCTION}

Glacier melt is controlled by meteorological conditions at the glacier surface and varies in different climates and throughout the year. Micrometeorological studies on glaciers facilitate calculation of point energy balances and partitioning of individual energy fluxes, thus providing the basis for distributed melt models. Furthermore, these studies reveal the usefulness of remote meteorological measurements needed for modeling mass-balance changes in the past.

Few micrometeorological investigations exist on the $\sim 200000$ glaciers in the world, although an increasing number of automatic weather stations (AWSs) are being installed to study the energy exchange on glaciers in different climates (Oerlemans, 2000; Klok and others, 2005; Sicart and others, 2005; Schneider and others, 2007; Giesen and others, 2009; Six and others, 2009). These studies focus on arctic, alpine or tropical glaciers.

In this paper, we present the 2008 energy balance for Sørbreen (15 km² $\sim 120-2200$ ma.s.l.), a glacier in a polar maritime climate on the island of Jan Mayen $\left(71^{\circ} 00^{\prime} \mathrm{N}\right.$, $8^{\circ} 30^{\prime} \mathrm{W}, 373 \mathrm{~km}^{2}$; Fig. 1). The local energy balance is calculated and compared with the corresponding specific mass balance. The components of the energy balance are analyzed and the relative contribution of each flux is calculated and compared with the total melt energy. The aim is to assess whether the mass balance can be reproduced using meteorological data measured on the glacier.

We also compare the AWS temperatures for two different altitudes at Sørbreen with air temperatures measured at corresponding altitudes with radiosondes, by the Norwegian Meteorological Institute (met.no), $\sim 20 \mathrm{~km}$ from the glacier. The purpose is to investigate how representative the radiosonde temperatures are at various altitudes on the glacier, with the intention of using radiosonde temperature profiles in distributed melt models for the glacier.

\section{GEOGRAPHICAL SETTING}

Jan Mayen is a Norwegian island situated in the North Atlantic Ocean (Fig. 1). It is a volcanic island with several observed eruptions since 1732 and it is the northernmost island on the Mid-Atlantic Ridge. The highest mountain, Beerenberg (2277 ma.s.I.), dominates the northern part of Jan Mayen, with 20 individual glaciers flowing down in all directions from the central crater (Orheim, 1993). The Beerenberg high cone formation was created 6000-7000 years BP (Birkenmajer, 2004).

The $15 \mathrm{~km}^{2}$ Sørbreen glacier on the southern side of Beerenberg $\left(71^{\circ} 02^{\prime} \mathrm{N}, 8^{\circ} 12^{\prime} \mathrm{W}\right.$; Fig. 1$)$ covers an elevation from $\sim 120$ to $2200 \mathrm{ma}$ a.s.l. The mean equilibrium-line altitude in the 1970s is estimated to have been $~ 950 \mathrm{~m}$ a.s.l. (Orheim, 1993). The glacier surface is uneven and highly crevassed (Fig. 2), possibly due to subglacial melt resulting from high geothermal heat and/or differential erosion of softer bedrock and harder lava rock.

Anda and others (1985) report two distinctive Holocene glacier advances, one at $2500 \mathrm{BP}$ and a maximum advance at AD 1850. Maps and sketches of the front position of Sørbreen exist from 1632. The smallest extent of the glacier front is documented in aerial photographs in 1949. The glacier front advanced a few hundred meters during the 1960s, but GPS profiles from October 2007 and satellite images from 2008 show that the front position of Sørbreen is now close to the 1949 position.

\section{LOCAL CLIMATE}

The climate on Jan Mayen is polar maritime, with small fluctuations in temperature during the seasons (Hov, 2004). The mean annual temperature for the last meteorological normal period 1961-90 (Fig. 3), at the met.no station (9 ma.s.l., $\sim 20 \mathrm{~km}$ southwest of Sørbreen; Fig. 1) was $-1.4^{\circ} \mathrm{C}$, and the lowest and highest monthly mean temperatures were $-6.1^{\circ} \mathrm{C}$ and $4.9^{\circ} \mathrm{C}$, respectively. The corresponding temperatures for the period $1991-2008$ were $0.1^{\circ} \mathrm{C},-3.9^{\circ} \mathrm{C}$ and $6.1^{\circ} \mathrm{C}$, respectively (http://eklima.no). This indicates a warming of $\sim 1.5^{\circ} \mathrm{C}$ in 30 years. In the periods $1961-90$ and 1991-2008 the annual precipitation was 682 and $654 \mathrm{~mm}$, respectively. This corresponds to a change in precipitation of $-4 \%$ (http://eklima.no). The period April-July has the lowest 

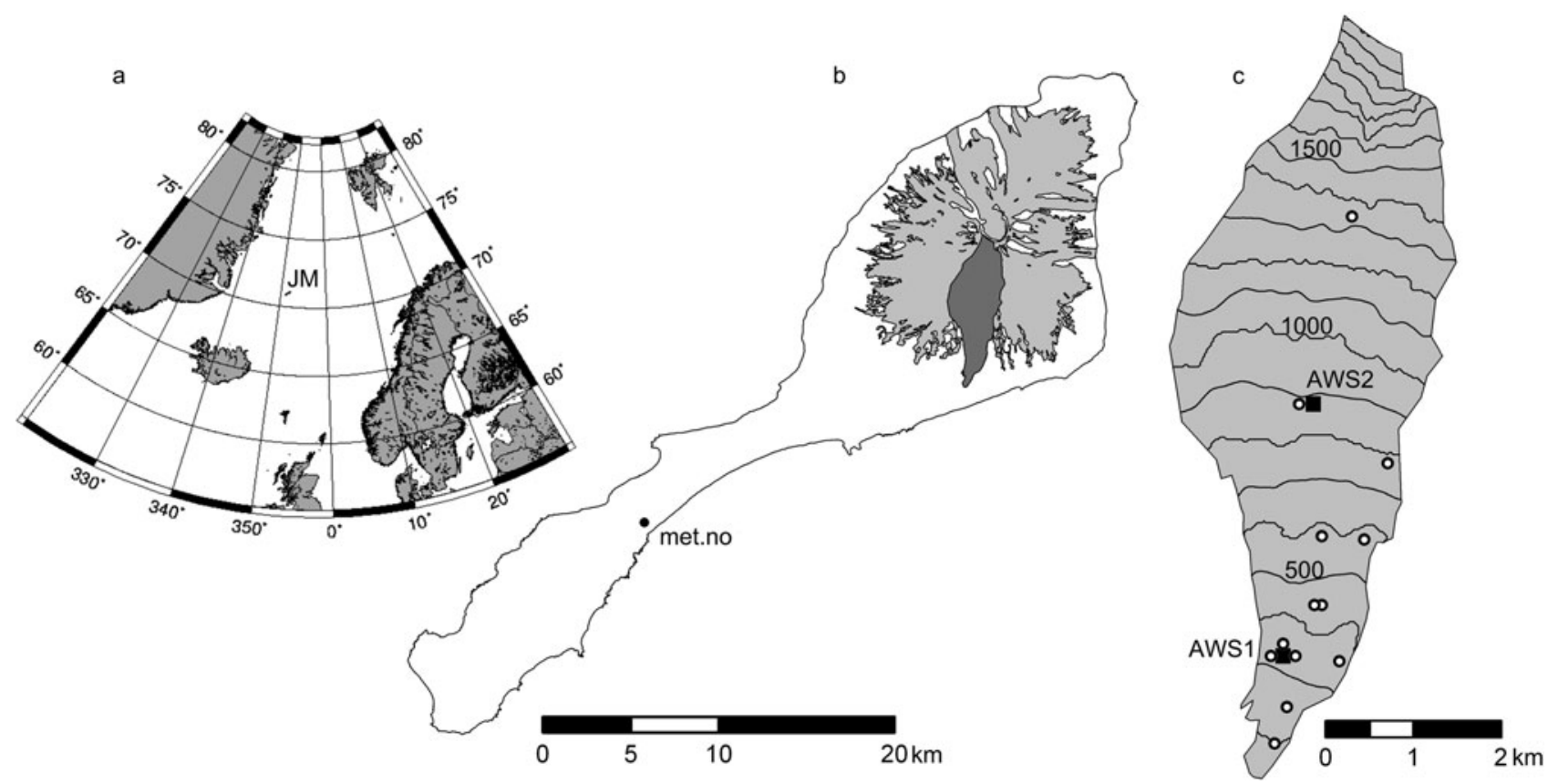

Fig. 1. (a) Location of Jan Mayen (JM) $550 \mathrm{~km}$ northeast of Iceland. (b) Outline of Jan Mayen, the glacierized area on the island (grey) and Sørbreen (dark grey). The position of the meteorological station, operated by met.no, is marked. (c) Topography of Sørbreen and contour lines with $100 \mathrm{~m}$ spacing, the position of the AWS (squares) and ablation stakes (dots) in 2008.

precipitation and the period September-December has the highest. Comparison of data from the periods 1961-90 and 1991-2008 (Fig. 3) shows higher precipitation during winter $(+7 \%)$ and lower precipitation during summer $(-19 \%)$. From the 1960s to the 1980s, sea ice was observed surrounding the island during winter (Orheim, 1993), but this is not the case now. The observed increase in air temperature and precipitation during winter is possibly a cause of the sea-ice retreat.

Empirical-statistical downscaled global climate models predict that the annual temperature will rise by $1.7^{\circ} \mathrm{C}$ and the annual precipitation total will increase by $12 \%$ on Jan Mayen by the end of the 21st century (Benestad, 2008).

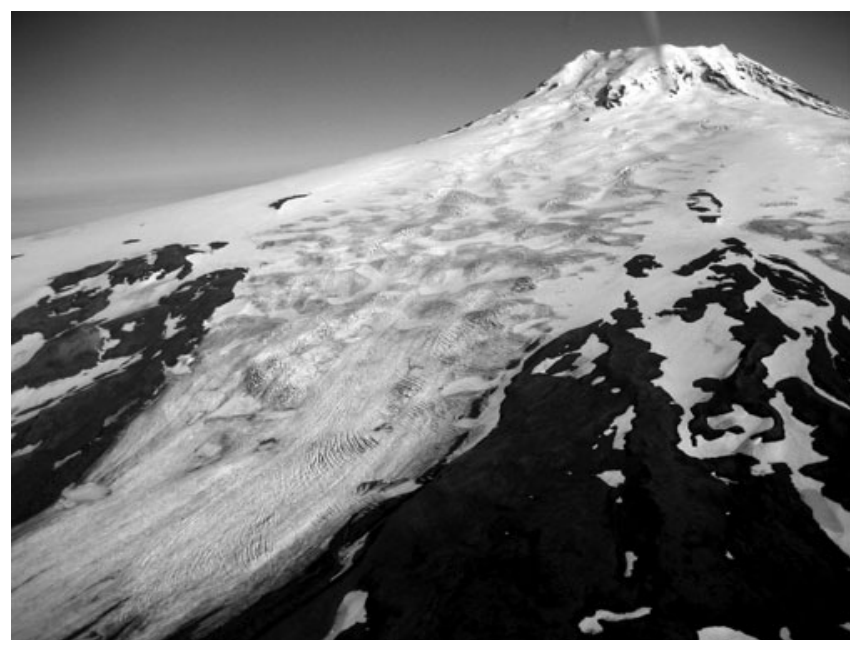

Fig. 2. Aerial photograph of Sørbreen and the central crater of Beerenberg from 24 July 2008 showing the irregular snowline and uneven topography, indicating a highly variable snow accumulation and resulting melt. Sørbreen is connected with Kronprins Olavs bre in the upper part and bounded by the east and west Sørbreen moraine in the lower part.
These predictions are based on multi-model assemblages of global climate model simulations, referred to as 'MMD' or 'CMIP3' in Meehl and others (2007) following the emission scenario A1B (Nakiáenoviá and others, 2000).

The weather on Jan Mayen is characterized by persistent cloud cover due to temperature inversion in the lower atmosphere (Fig. 4). This affects the vertical air-temperature distribution (lapse rate) above the glacier surface and also the incoming radiation. The top of the clouds is generally below 1000 ma.s.l. while Sørbreen extends up to $2200 \mathrm{~m}$ a.s.I., resulting in a significantly higher shortwave radiation on the upper part of the glacier.

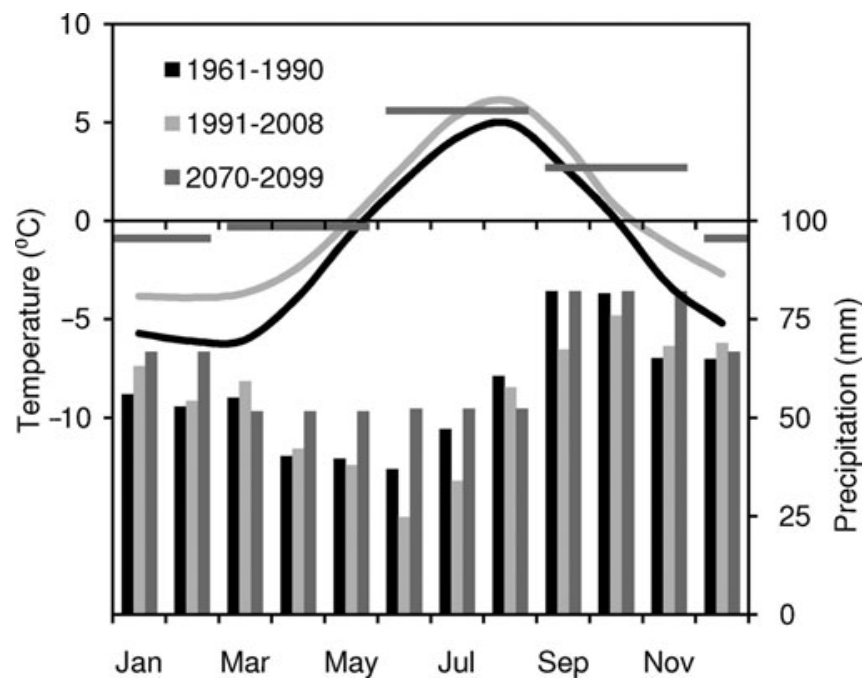

Fig. 3. Monthly mean temperature and precipitation at the met.no station in the meteorological normal period 1961-90, the present period 1991-2008 (http://eklima.no) and predicted 3 month mean values from global climate models for the period 2070-99 (Benestad, 2008). 


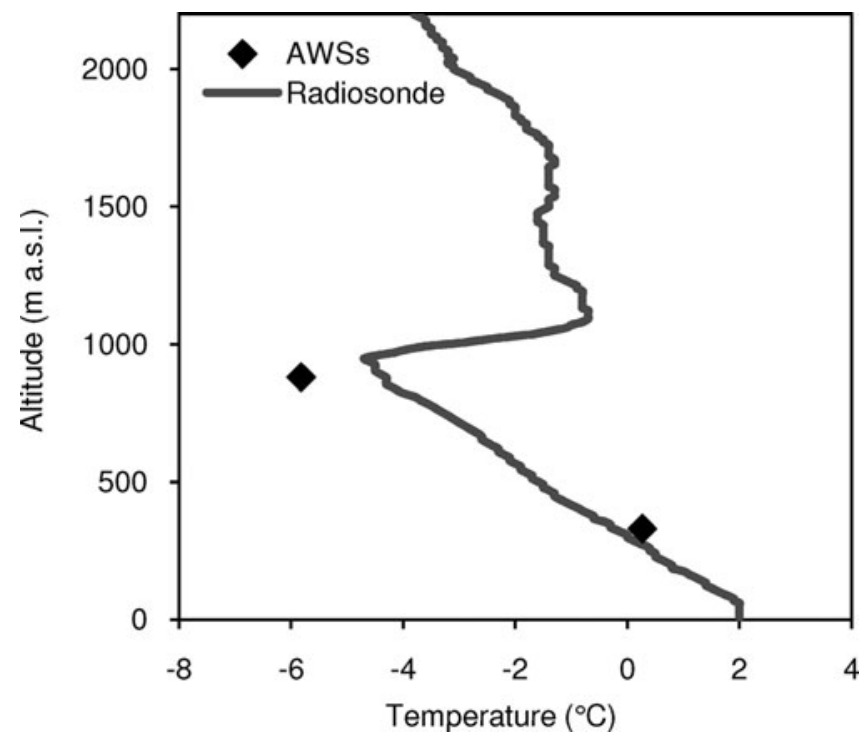

Fig. 4. Example of temperature inversion on Jan Mayen. Air temperatures measured at AWS1 (330 ma.s.I.), AWS2 (880 ma.s.I.) and the radiosonde release at met.no station on 4 September 2008, $2312 \mathrm{~h}$.

\section{Mass-balance and meteorological data}

The winter and summer balances for Sørbreen were measured by Orheim (1976) in 1972/73 and 1973/74 and some additional ablation measurements were conducted in the summers of 1976 and 1977 (Hagen, 2004). Since 2007/08, mass-balance measurements on Sørbreen have been conducted by the Norwegian University of Life Sciences (UMB) using snow probing, snow density measurements and ablation stakes drilled into the ice/firn (Østrem and Brugman, 1991). In total, 85 snow-depth measurements, two snow pits and 13 ablation stakes are available for calculation of the mass balance for 2007/08. Winter mass balance was measured from 29 March to 1 April 2008 and summer measurements were conducted from 2 to 6 October 2008.

An AWS (AWS1; Fig. 5) was installed in October 2007 at $330 \mathrm{~m}$ a.s.l. in the ablation area (Fig. 1). This part of the glacier surface is relatively flat and homogeneous. The mast is $\sim 5 \mathrm{~m}$ high. AWS1 has collected 1 year of continuous data, except for 4 days of data in July missing due to a memory card error. Data are sampled at different time intervals depending on the instrument (Table 1), and mean values are stored on a data logger every $15 \mathrm{~min}$. AWS1 is a floating station that stands free on the ice and sinks with the melting surface. The advantage of this construction is that it keeps a constant instrument height once the glacier surface is snowfree. Measured parameters are air temperature and humidity, wind speed and direction, barometric pressure, incoming and outgoing shortwave and longwave radiation, snow depth and snow and ice temperatures. The radiation fluxes measured with the Campbell CNR1 sensor are not heated due to limited available electrical power. However, there have been few problems with riming at the location and the data seem to be of good quality. Due to the insufficient power supply, the temperature sensors on the glacier are not artificially ventilated and this may impair the accuracy, as stated by the manufacturer (Table 1 ).

In order to investigate elevation gradients in air temperatures on the glacier, one AWS (AWS2) was installed on the central flowline in the upper ablation area at $880 \mathrm{~m}$ a.s.l.

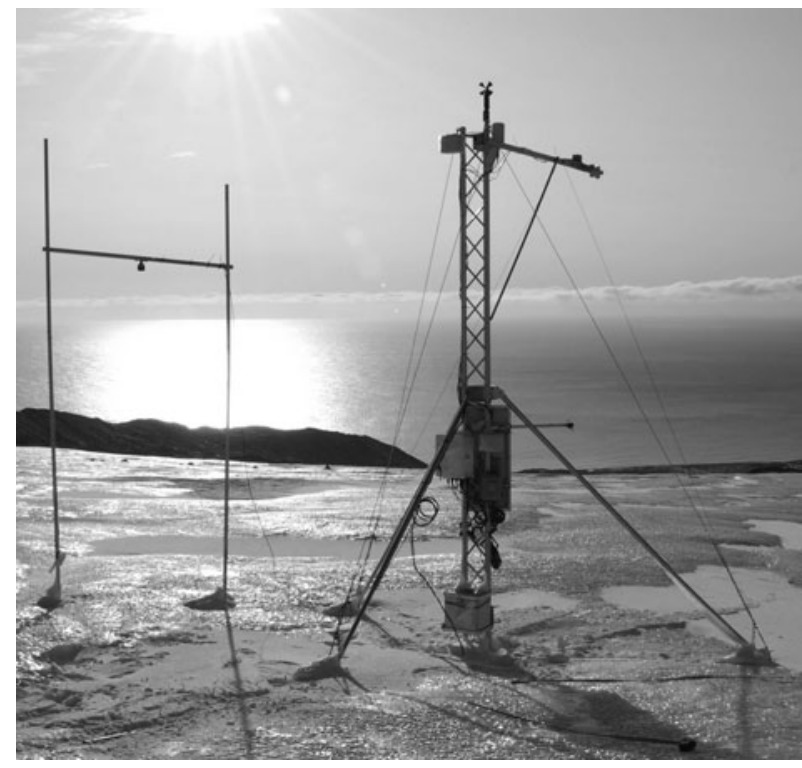

Fig. 5. Photograph of AWS1 at 330 m a.s.I. on Sørbreen, 2 October 2008. The mast is $5 \mathrm{~m}$ high and stands freely on the ice (photograph by K. Breili).

(Fig. 1). This station was installed on 1 April 2008. AWS2 measures air temperature and relative humidity $(\mathrm{RH})$ (Table 1 ) and it is mounted on a stake fixed in the ice.

The meteorological station on Jan Mayen was established in September 1921 when the Norwegian Meteorological Institute occupied the island. The station has been relocated several times but has remained at its present position since 25 August 1969 (Førland and others, 1997). Daily mean and homogeneous monthly data of temperatures and precipitation are available from 1921 to the present, with some minor gaps during World War II (Nordli and others, 1996). Hourly data of air temperature, humidity, air pressure, precipitation, wind speed and wind direction are available since 1996. Full synoptic observations with cloud cover, etc., are available every sixth hour since 1956 (http:// eklima.no).

Radiosondes have been deployed twice a day at the meteorological station since 1949. The balloon travels to a height of $25000-30000 \mathrm{~m}$ and, during the ascent, measurements of air temperature, humidity, air pressure and wind speed are recorded every $2 \mathrm{~s}(\sim 10 \mathrm{~m}$ intervals). Prior to 1994 data were stored for fixed pressure levels (e.g. 1000, 850,700 mbar), whereas high-resolution data files exist after 1994.

\section{DATA TREATMENT}

All times and dates are given as Universal Time Coordinated (UTC), introducing a shift of $\sim 34$ min to the true solar time on Jan Mayen. Meteorological data were quality-checked and corrected if beyond plausible limits. If shortwave incoming radiation $(S \downarrow)$ is smaller than reflected shortwave radiation $(S \uparrow)$, it is assumed that there is snow on the top of the instrument and $S \downarrow$ is set as $S \uparrow / 0.9$. The shortwave radiation measurements are sensitive to tilting of the instrument and sun elevations (Jonsell and others, 2003). No significant tilting of the mast has been observed and no corrections are therefore applied. The daily averaged albedo $(\alpha)$ is calculated as the ratio of the daily totals of $S \uparrow$ and $S \downarrow$. To avoid 
Table 1. Measured variables at AWS1 and AWS2 on Sørbreen and radiosonde measurements from the met.no station. Mean values are stored every $15 \mathrm{~min}$ at the AWS. Radiosondes are released twice daily from the met.no station and measurements are stored every $2 \mathrm{~s}$ (i.e. $10 \mathrm{~m}$ intervals)

Variable $\quad$ Sensor $\quad$ Sampling rate Instrument height Range Accuracy

$\mathrm{m}$

\section{AWS1}

Air temperature

Air humidity

Wind speed

Wind direction

Barometric pressure

Global and reflected shortwave radiation

Incoming and outgoing longwave radiation

Surface height

Snow temperatures

Ice temperatures

AWS2

Air temperature

Air humidity

Radiosonde

Air temperature

Air humidity

Barometric pressure

Vaisala HMP45A
Vaisala HMP45A
R.M Young 5103 Alpine
R.M Young 5103 Alpine
Setra 278
Kipp \& Zonen CNR1
Kipp \& Zonen CNR1
Campbell SR50A
Onset S-TMB
Onset S-TMB
Onset S-THB
Onset S-THB
Vaisala RS80, Thermocap
Vaisala RS80, Humicap
Vaisala RS80, Barocap

$\begin{array}{cc}15 \mathrm{~s} & 4.8 \\ 15 \mathrm{~s} & 4.8 \\ 5 \mathrm{~s} & 5.0 \\ 5 \mathrm{~s} & 5.0 \\ 15 \mathrm{~min} & 1.5 \\ 15 \mathrm{~s} & 4.8 \\ 15 \mathrm{~s} & 4.8 \\ 15 \mathrm{~min} & - \\ 15 \mathrm{~min} & 0-1.25 \\ 15 \mathrm{~min} & 0 \text { to }-7 \\ & \\ 15 \mathrm{~s} & \text { Varies } \\ 15 \mathrm{~s} & \text { Varies }^{\ddagger}\end{array}$

$$
\begin{array}{cc}
-40^{\circ} \mathrm{C} \text { to } 60^{\circ} \mathrm{C} & \pm 0.3^{\circ} \mathrm{C}^{*} \\
0-100 \% \mathrm{RH} & \pm 3 \% \mathrm{RH}^{*} \\
1-100 \mathrm{~m} \mathrm{~s}^{-1} & \pm 0.3 \mathrm{~m} \mathrm{~s}^{-1} \text { or } 1 \% \\
0-355^{\circ} & \pm 3^{\circ} \\
600-1100 \mathrm{mbar} & \pm 1.5 \mathrm{mbar} \\
305-2800 \mathrm{~nm} & \pm 10 \%{ }^{\dagger} \\
4.5-42.0 \mu \mathrm{m} & \pm 10 \% \\
0.5-10.0 \mathrm{~m} & \pm 1 \mathrm{~cm} \mathrm{or} 0.4 \%^{\dagger} \\
-40^{\circ} \mathrm{C} \text { to } 100^{\circ} \mathrm{C} & \pm 0.3^{\circ} \mathrm{C}^{*} \\
-40{ }^{\circ} \mathrm{C} \text { to } 100^{\circ} \mathrm{C} & \pm 0.3^{\circ} \mathrm{C}^{*} \\
& \\
-40{ }^{\circ} \mathrm{C} \text { to } 75^{\circ} \mathrm{C} & \pm 0.3^{\circ} \mathrm{C}^{*} \\
0-100 \% \mathrm{RH} & \pm 3.5 \% \mathrm{RH}^{*}
\end{array}
$$

$$
\begin{array}{cc}
-90^{\circ} \mathrm{C} \text { to } 60^{\circ} \mathrm{C} & \pm 0.5^{\circ} \mathrm{C} \\
0-100 \% \mathrm{RH} & \pm 5 \% \mathrm{RH} \\
3-1060 \mathrm{mbar} & \pm 1 \mathrm{mbar}
\end{array}
$$

Note: All accuracies are given by the manufacturer and do not include errors related to the installation and the use of the instruments.

*Accuracy is stated for the temperature interval used in this study.

'Expected accuracy for daily sums.

${ }^{\ddagger}$ Air temperatures at AWS2 are compensated for the changing measurement heights, following Oerlemans (2000).

overestimation of the outgoing longwave radiation $(L \uparrow)$ from the surface, a maximum radiation flux of $316 \mathrm{~W} \mathrm{~m}^{-2}$ is assumed, corresponding to the radiation emitted from a $0^{\circ} \mathrm{C}$ black body.

Snow density was measured on 29 and 30 March 2008 in two snow pits close to AWS1 and AWS2. The snow depth at AWS1 was $90 \mathrm{~cm}$ and at AWS2 was $219 \mathrm{~cm}$. A logarithmic function is fitted to the measured densities:

$$
\rho_{\mathrm{s}}=0.035 \ln \left(d_{\mathrm{s}}\right)+0.31,
$$

where $\rho_{\mathrm{s}}$ is the snow density at snow depth $d_{\mathrm{s}}$. Equation (1) is integrated to calculate the snow water equivalent (SWE) for measured snow depths.

Surface elevation change is measured with an ultrasonic ranger as a proxy for mass change. According to the record from the ultrasonic ranger the melt started on 25 April 2008 and ended close to 30 September 2008. Albedo and snow depth data show that the ice surface was snow-free from 8 June 2008. It is this 115 day long snow-free period that is analyzed in this study, and this period is hereafter referred to as the ice-melt season. Limiting the calculations to the snowfree period is recommended by Rolstad and Oerlemans (2005), who assessed the error propagation for energy balance and melt calculations for a similar dataset.

The instrument height at AWS2 varied throughout the season. Therefore, air temperatures have been compensated accordingly. The method of Oerlemans (2000), assuming a logarithmic temperature profile close to the glacier surface, provides the $2 \mathrm{~m}$ temperatures above the ice surface. The constant $\mu$ in Equations (8a) and (9) of Oerlemans (2000) is calibrated to 0.100 in our study, using temperature data at two levels from AWS1 and assuming equal values for AWS2.
Air temperatures measured with radiosonde and the two AWSs at 330 and 880 ma.s.I. on Sørbreen (Wedøe-Rødby, 2009) are compared for these altitudes. Owing to the twicedaily radiosonde releases, differences can be calculated at two times per day. Data for 1 year (October 2007 to September 2008) are used in the comparison of the temperatures at $330 \mathrm{~m}$, and data for 6 months (AprilSeptember 2008) are used in the comparison of the temperatures at $880 \mathrm{~m}$. Expected measurement errors from the instruments are estimated as $\pm 0.6^{\circ} \mathrm{C}$ by the equation

$$
\delta \Delta T=\sqrt{\left(\delta T_{\mathrm{RS}}\right)^{2}+\left(\delta T_{\mathrm{AWS}}\right)^{2}},
$$

where $\delta \Delta T$ is the estimated error of the temperature differences. $\delta \Delta T_{\mathrm{RS}}\left(0.5^{\circ} \mathrm{C}\right)$ and $\delta \Delta T_{\mathrm{AWS}}\left(0.3^{\circ} \mathrm{C}\right)$ are the maximum expected instrument errors (Table 1 ).

\section{CALCULATION OF THE ENERGY BALANCE AND THE RESULTING MELT}

Surface energy balance is calculated for the ice-melt season at AWS1. Calculations are made with 15 min time-steps, and daily and monthly means and diurnal cycles are compiled. The following equations are used:

$$
\begin{gathered}
Q_{\mathrm{M}}=Q_{\mathrm{N}}+Q_{\mathrm{H}}+Q_{\mathrm{E}}+Q_{\mathrm{G}}+Q_{\mathrm{R}} \\
Q_{\mathrm{N}}=S_{\text {net }}+L_{\text {net }}=S \downarrow+S \uparrow+L \downarrow+L \uparrow,
\end{gathered}
$$

where $Q_{M}$ is energy available for melt, $Q_{N}$ is the net radiation, $Q_{\mathrm{H}}$ and $Q_{\mathrm{E}}$ are sensible and latent turbulent heat fluxes, $Q_{\mathrm{G}}$ is the ground (ice) heat flux, $Q_{\mathrm{R}}$ is the sensible heat flux from rain, $S_{\text {net }}$ and $L_{\text {net }}$ are the net short- and longwave radiation, respectively, and $L \downarrow$ is the incoming 


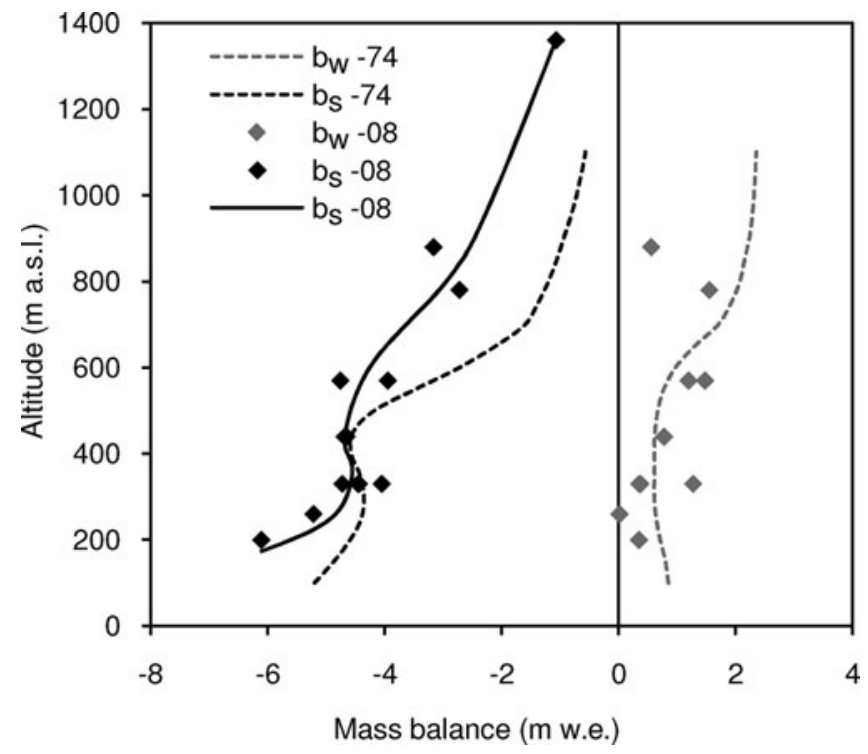

Fig. 6. Winter $\left(b_{\mathrm{w}}\right)$ and summer $\left(b_{\mathrm{s}}\right)$ mass balance at the ablation stakes on Sørbreen in 2007/08 and mass-balance profiles in 1973/74. Note that some of the 13 stakes used in 2008 are positioned close to each other and show almost identical values. A manually interpreted ablation profile in 2008 is shown for comparison with the ablation profile in 1974 .

longwave radiation (Hock, 2005). Fluxes toward the surface are defined as positive.

Short- and longwave radiations are measured directly at the AWS, while the other fluxes are parameterized from measured meteorological parameters. Turbulent heat fluxes are computed using the bulk aerodynamic method (Munro, 1990) and air temperature, RH and wind-speed data from AWS1, and calculated surface temperature from the longwave radiation measurement. In case of stable stratification, the stability functions for momentum, heat and humidity are computed according to Beljaars and Holtslag (1991) and the sensible heat flux is solved by an iterative scheme.

The roughness lengths of heat $\left(z_{\mathrm{t}}\right)$ and moisture $\left(z_{\mathrm{e}}\right)$ are assumed to be one order of magnitude smaller than the roughness length of momentum $\left(z_{0}\right)$, and are manually scaled to fit calculated melt to measured melt from the ultrasonic ranger $\left(z_{0}=9.0 \mathrm{~mm} ; z_{\mathrm{t}}=z_{\mathrm{e}}=0.9 \mathrm{~mm}\right)$.

Sørbreen is a polythermal glacier with a cold surface layer. A small part of the energy available is used to warm up the snow and ice before melting begins. This ground (ice) heat flux is known to be highest during spring, when the snowpack is heated and just after the snow disappears (Hock and Holmgren, 1996). This study focuses on the snow-free period when the ground (ice) heat flux is expected to be small. The available ice temperature data from 2008 are from shallow depths only, due to drilling problems when installing the temperature sensors. Evaluating the ice temperature measurements, the average ground (ice) heat flux for the investigated period is found to be small, approximately $-1 \mathrm{~W} \mathrm{~m}^{-2}$, and is therefore neglected in the calculation of the energy balance.

Rain heat flux is derived from precipitation measurements at the met.no station. The measured precipitation rate at the met.no station is assumed valid for the glacier, and the temperature of the rain is assumed to be the air temperature of AWS1.

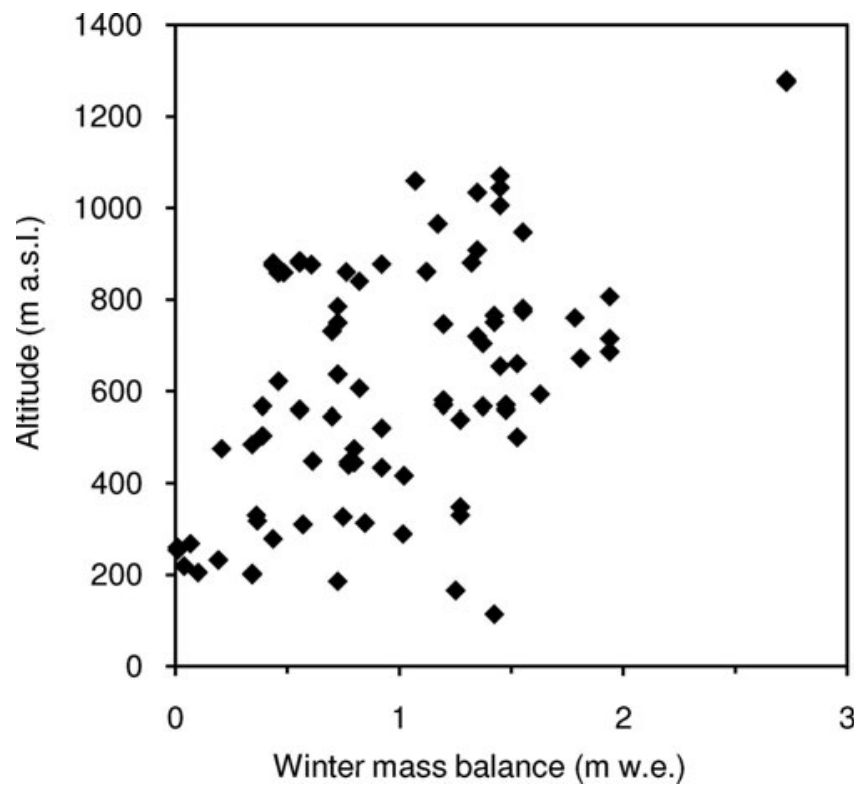

Fig. 7. Winter mass balance at probing points on Sørbreen 29 March to 1 April 2008.

Surface melt $(M)$ is calculated as

$$
M=\frac{Q_{M}^{+}}{\rho_{\mathrm{W}} L_{f}}
$$

where $Q_{M}{ }^{+}$is the positive energy available for melt, $\rho_{\mathrm{W}}$ is the density of water $\left(1000 \mathrm{~kg} \mathrm{~m}^{-3}\right)$ and $L_{\mathrm{f}}$ is the latent heat of fusion $\left(0.334 \times 10^{6} \mathrm{~J} \mathrm{~kg}^{-1}\right)$.

\section{RESULTS AND DISCUSSION} Specific mass balances

Specific winter and summer balances for 2008 are presented for 13 stakes in Figure 6. The winter balance is based on measurements made from 29 March to 1 April 2008, and the summer balance was measured in the first week in October 2008. Measured summer balances are assumed valid for 30 September since very little melt occurred during this time period. The ideal time to measure the winter balance may be later in the season, but this could not be done for logistical reasons, so both winter and summer balances may be underestimated. However, a more challenging feature for calculation of the winter mass balance is the large spatial variation in the snow distribution (Fig. 7). The uneven topography of Sørbreen and wind-transported accumulation result in a very inhomogeneous snow distribution, which has been observed in the field, in aerial photographs (Fig. 2) and in satellite images as an irregular snowline. Crevasses on the small 'hilltops' inhibit snow depth and ablation measurements. Measurements are conducted mostly in small valleys or on flat parts of the glacier. The accumulation may be overestimated due to this spatial bias.

Ablation measurements in 2008 show a vertical distribution similar to the ablation measurements conducted in the 1970s, indicating a non-linear ablation profile (Fig. 6). Orheim (1976) suggests that the sudden change in summer mass-balance profile at $\sim 400$ ma.s.l. is a result of the persistent temperature inversion at the lower elevations of the glacier. The temperature inversion affects the air temperature on the glacier, and also the incoming radiation 


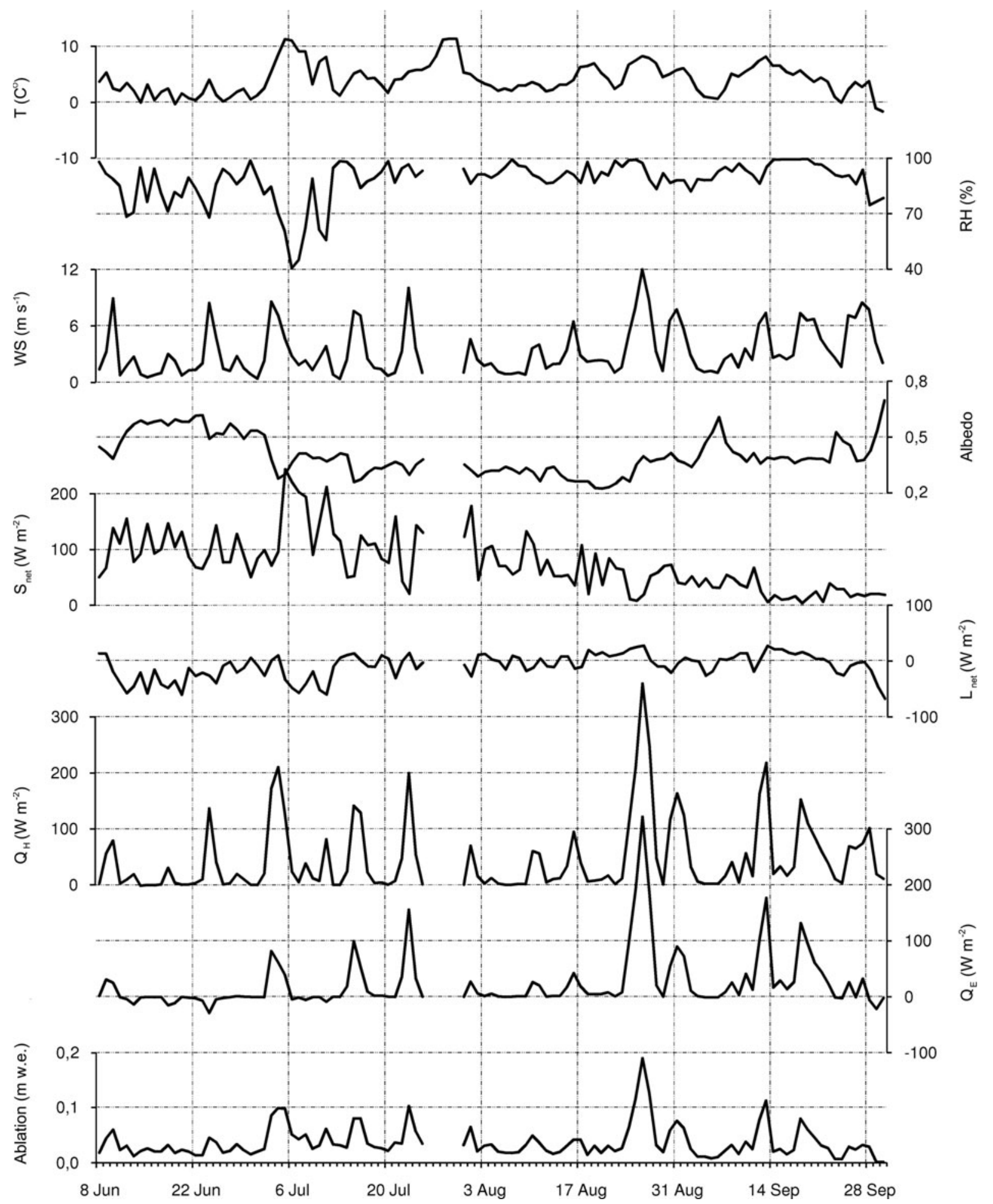

Fig. 8. Daily mean values at AWS1 of air temperature $(T)$, relative humidity $(\mathrm{RH})$, wind speed (WS), albedo, net shortwave radiation $\left(S_{\text {net }}\right)$, net longwave radiation $\left(L_{\text {net }}\right)$, sensible heat flux $\left(Q_{\mathrm{H}}\right)$, latent heat flux $\left(Q_{\mathrm{E}}\right)$ and ablation for the 115 day snow-free period from 8 June to 30 September 2008.

to the glacier surface due to the persistent cloud cover. Previous studies by Trondsen (2008) show that a temperature inversion exists almost every day and the layers are thicker and more frequent during summer. The inhomogeneous snow distribution suggests that melt will also be inhomogeneous, as the snow cover greatly influences the albedo of the glacier surface. The manually drawn ablation profile in 2008 shows equal melt rates at 330-570 ma.s.l. (Fig. 6). However, the point measurements may not be representative of the spatial distribution of the melt. More measurements and further investigations are needed to evaluate the impact of the temperature inversion layers on the melt rates.

\section{Meteorological conditions at AWS1}

The air temperature at the $4.8 \mathrm{~m}$ level varied between $-2.1^{\circ} \mathrm{C}$ and $15.0^{\circ} \mathrm{C}$, with a mean temperature of $4.2^{\circ} \mathrm{C}$ during the ice-melt season. Daily mean temperatures are illustrated in Figure 8 . The warmest month was July, with a monthly mean 

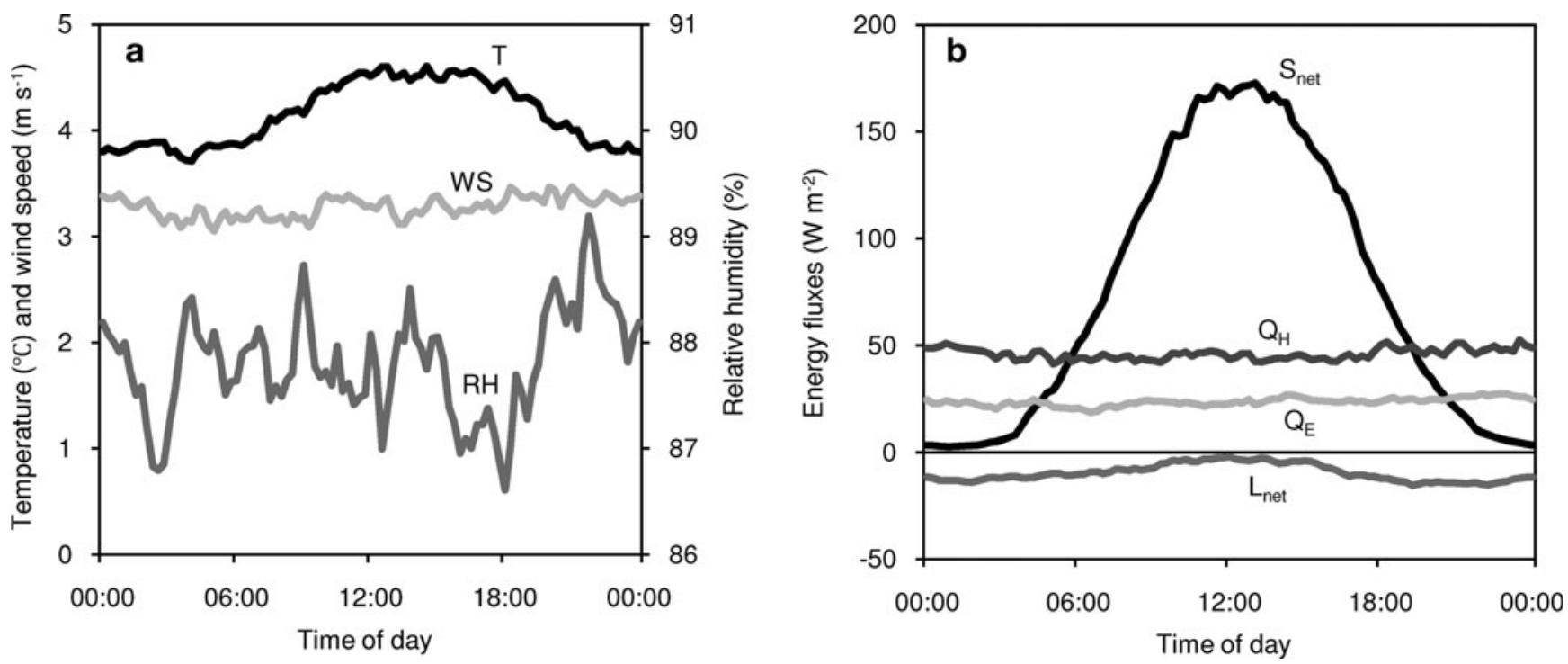

Fig. 9. (a) Mean diurnal cycle of temperature (T), relative humidity (RH), wind speed (WS) and (b) energy fluxes for AWS1 from 8 June to 30 September 2008.

temperature of $6.2^{\circ} \mathrm{C}$ (Table 2). The diurnal cycle shows small variation from $3.7^{\circ} \mathrm{C}$ to $4.6^{\circ} \mathrm{C}$, with higher temperatures during the day and lower temperatures at night (Fig. 9).

The $\mathrm{RH}$ is high, with small seasonal and diurnal variations. The mean $\mathrm{RH}$ for the melting season is $88 \%$, with a mean monthly variation from $82 \%$ to $92 \%$ (Table 2 ). There is no pronounced diurnal cycle of RH (Fig. 9).

The general wind speed and direction is highly influenced by the glacier wind flow and varies from north to east (Fig. 10), which corresponds with the orientation of the glacier. High wind speeds are suggested to be a combination of glacier winds with a synoptic and/or topographic forcing. The mean wind speed for the period is $3.3 \mathrm{~m} \mathrm{~s}^{-1}$ (Table 2), with a maximum daily mean of $12.0 \mathrm{~m} \mathrm{~s}^{-1}$ (Fig. 8) and the highest wind gust of $30.1 \mathrm{~m} \mathrm{~s}^{-1}$. There is no pronounced seasonal cycle, but a weak diurnal cycle with slightly lower winds during daytime (Fig. 9).

\section{Energy fluxes and ablation at AWS1}

Incoming shortwave radiation, $S \downarrow$, shows a mean value of $132 \mathrm{~W} \mathrm{~m}^{-2}$ indicating generally overcast conditions if compared with the calculated mean top-of-atmosphere (TOA) radiation of $345 \mathrm{~W} \mathrm{~m}^{-2}$ (Table 2). The seasonal variation is high, as expected, due to TOA variations but also because of a more consistent cloud cover in August and September compared with the period May-July (http:// eklima.no). The diurnal cycle follows a sinus shape, with mean values of $296 \mathrm{~W} \mathrm{~m}^{-2}$ during the day and close to zero

Table 2. Seasonal and monthly mean values of measured and calculated variables at AWS1 from 8 June to 30 September 2008

\begin{tabular}{|c|c|c|c|c|c|}
\hline Variable & Ice-melt season & Jun. & Jul. & Aug. & Sep. \\
\hline \multicolumn{6}{|l|}{ Measured variables } \\
\hline Temperature $\left({ }^{\circ} \mathrm{C}\right)$ & 4.2 & 1.7 & 6.2 & 4.5 & 3.5 \\
\hline Relative humidity (\%) & 88 & 84 & 82 & 92 & 91 \\
\hline Wind speed $\left(\mathrm{m} \mathrm{s}^{-1}\right)$ & 3.3 & 2.3 & 3.2 & 3.4 & 4.0 \\
\hline Barometric pressure (hPa) & 972 & 976 & 974 & 972 & 968 \\
\hline Shortwave in, $S \downarrow\left(\mathrm{W} \mathrm{m}^{-2}\right)$ & 132 & 221 & 198 & 90 & 47 \\
\hline Shortwave out, $S \uparrow\left(\mathrm{W} \mathrm{m}^{-2}\right)$ & 56 & 120 & 72 & 28 & 21 \\
\hline Longwave in, $L \downarrow\left(\mathrm{W} \mathrm{m}^{-2}\right)$ & 310 & 290 & 307 & 323 & 315 \\
\hline Longwave out, $L \uparrow\left(\mathrm{W} \mathrm{m}^{-2}\right)$ & 320 & 316 & 322 & 321 & 319 \\
\hline \multicolumn{6}{|l|}{ Calculated variables } \\
\hline TOA radiation $\left(\mathrm{W} \mathrm{m}^{-2}\right)$ & 345 & 494 & 447 & 310 & 161 \\
\hline Transmissivity & 0.38 & 0.45 & 0.44 & 0.29 & 0.29 \\
\hline Net shortwave radiation, $S_{\text {net }}\left(\mathrm{W} \mathrm{m}^{-2}\right)$ & 76 & 100 & 126 & 62 & 26 \\
\hline Net longwave radiation, $L_{\text {net }}\left(\mathrm{W} \mathrm{m}^{-2}\right)$ & -10 & -26 & -15 & 2 & -4 \\
\hline Sensible heat flux, $Q_{\mathrm{H}}\left(\mathrm{W} \mathrm{m}^{-2}\right)$ & 46 & 18 & 52 & 58 & 50 \\
\hline Latent heat flux, $Q_{\mathrm{E}}\left(\mathrm{W} \mathrm{m}^{-2}\right)$ & 24 & -1 & 22 & 39 & 28 \\
\hline Ground (ice) heat flux, $Q_{G}\left(\mathrm{~W} \mathrm{~m}^{-2}\right)$ & $\sim(-1)$ & - & - & - & - \\
\hline Rain heat flux, $Q_{R}\left(\mathrm{~W} \mathrm{~m}^{-2}\right)$ & 0.3 & 0.0 & 0.3 & 0.4 & 0.6 \\
\hline Melt flux, $Q_{M}\left(\mathrm{~W} \mathrm{~m}^{-2}\right)$ & 136 & 91 & 185 & 161 & 99 \\
\hline Melt rate $(\mathrm{m})$ & 4.14 & 0.57 & 1.44 & 1.31 & 0.82 \\
\hline
\end{tabular}




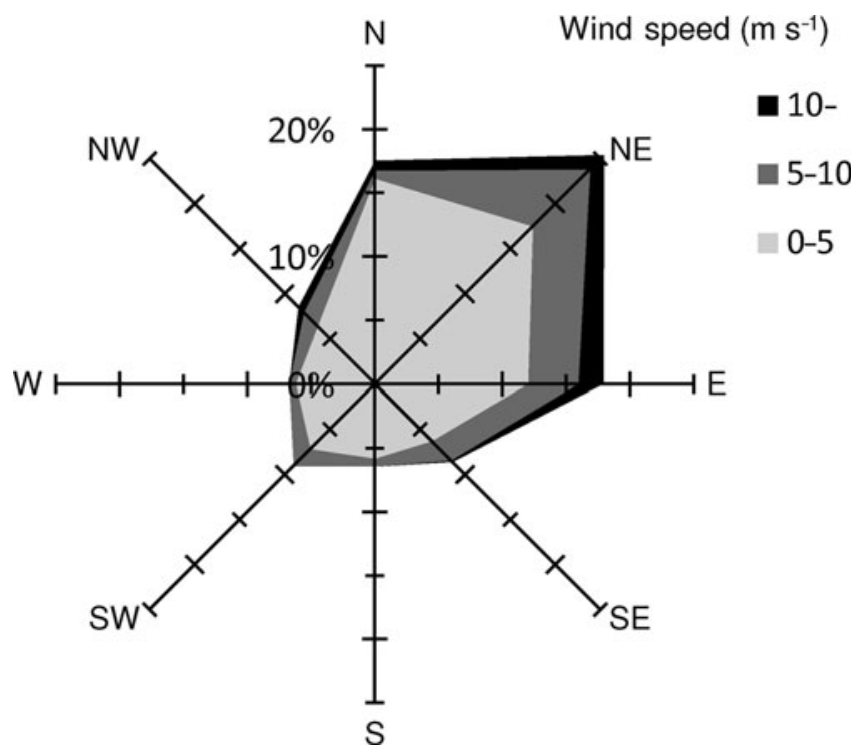

Fig. 10. Frequency distributions of $15 \mathrm{~min}$ mean values of wind speed and direction at AWS1 from 8 June to 30 September 2008.

at night. The net shortwave radiation, $S_{\text {net, }}$ is greatly reduced in August and September because of the lower $S \downarrow$, but also as a result of the higher albedo caused by small snowfalls at the end of August and beginning of September $\left(\alpha_{\text {Sep }}=0.45\right)$.

Incoming longwave radiation, $L \downarrow$, is the largest source of energy to the glacier surface. However, this is cancelled out by the high longwave outgoing irradiance, $L \uparrow$, making $L_{\text {net }}$ close to zero or slightly negative (Table 2; Fig. 8). The seasonal and diurnal variations in the net longwave radiation are low (Figs 8 and 9).

The net radiation, $Q_{N}$, is the largest energy supply to the surface energy balance over the calculated ice-melt period at AWS1. The relative contribution from $Q_{N}$ to the energy balance changes strongly during the summer, from $81 \%$ in June to $21 \%$ in September (Fig. 11). This is mainly an effect of the TOA reduction, but is also due to the more overcast conditions, resulting in a lower transmissivity, at the end of the summer.

Daily means in $Q_{\mathrm{H}}$ are highly variable, with values from about zero up to $360 \mathrm{~W} \mathrm{~m}^{-2}$ for days with high wind speeds and high air temperatures. Mean diurnal variations are low.

Latent heat flux, $Q_{E}$, is generally positive, representing condensation to the glacier surface. Seasonal variations are high, with a monthly mean value of $-1 \mathrm{~W} \mathrm{~m}^{-2}$ in June and $39 \mathrm{~W} \mathrm{~m}^{-2}$ in August (Table 2), and the daily mean value varies from -29 to $322 \mathrm{~W} \mathrm{~m}^{-2}$. As for $Q_{H}$, the diurnal variations are small or non-existent (Fig. 9).

The surface energy balance, $Q_{M}$, is positive for the entire ice-melt season on a daily scale, but negative $13 \%$ of the time if calculated on a $15 \mathrm{~min}$ timescale. The mean for the ice-melt season is $136 \mathrm{~W} \mathrm{~m}^{-2}$.

The calculated mean daily melt rate is $3.6 \mathrm{~cm} \mathrm{~d}^{-1}$, with peaks of $10-20 \mathrm{~cm} \mathrm{~d}^{-1}$ associated with days with high wind speeds. The total calculated melt for the period is $4.14 \mathrm{~m}$. Figure 12 shows calculated melt by the energy-balance model and measured melt from the ultrasonic ranger and three ablation stakes close to the weather station. The energy-balance model catches the variability in the melt rate reasonably well and corresponds well with the total melt for

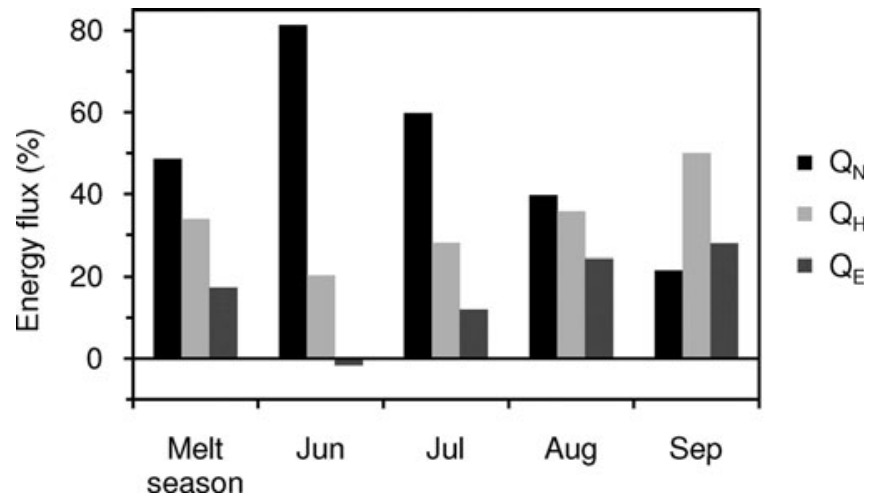

Fig. 11. Fraction of the energy fluxes of the total melt flux (\%) for the ice-melt season (8 June to 30 September) and the individual summer months in 2008.

the investigated period. This suggests that the energybalance model includes the main processes affecting the surface melt.

\section{Radiosonde and AWS air-temperature comparison}

Measurements of air temperatures at the AWS and the corresponding altitude at twice-daily radiosonde releases show a generally good agreement (Fig. 13). The correlation for AWS1 is $R^{2}=0.96$, the standard deviation of the residuals is $1.5^{\circ} \mathrm{C}$ and the mean difference is $0.1^{\circ} \mathrm{C}$. The corresponding values for AWS2 are $0.94,1.5^{\circ} \mathrm{C}$ and $-0.2^{\circ} \mathrm{C}$, respectively (Wedøe Rødby, 2009).

The high correlation indicates that the radiosonde temperatures are representative for temperatures at Sørbreen. Discrepancies are nevertheless detected throughout the measuring periods for short intervals (Wedøe Rødby, 2009). In general, analyses of radiosonde profiles show that there seems to be a connection with low-altitude inversions and observed discrepancies in temperatures of radiosonde and AWS data. A possible reason for some of the observed

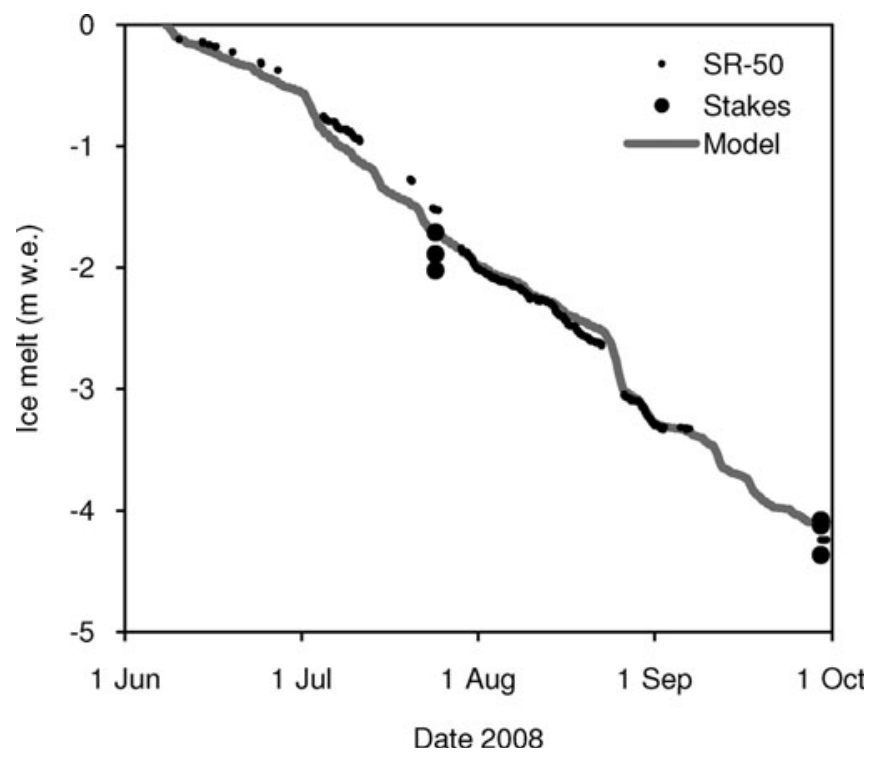

Fig. 12. Measured and calculated ice melt at AWS1 in 2008. Ice melt is measured with a Campbell Scientific SR-50A ultrasonic ranger and three ablation stakes within $5 \mathrm{~m}$ of the AWS. Modeled melt is computed with an energy-balance model. 

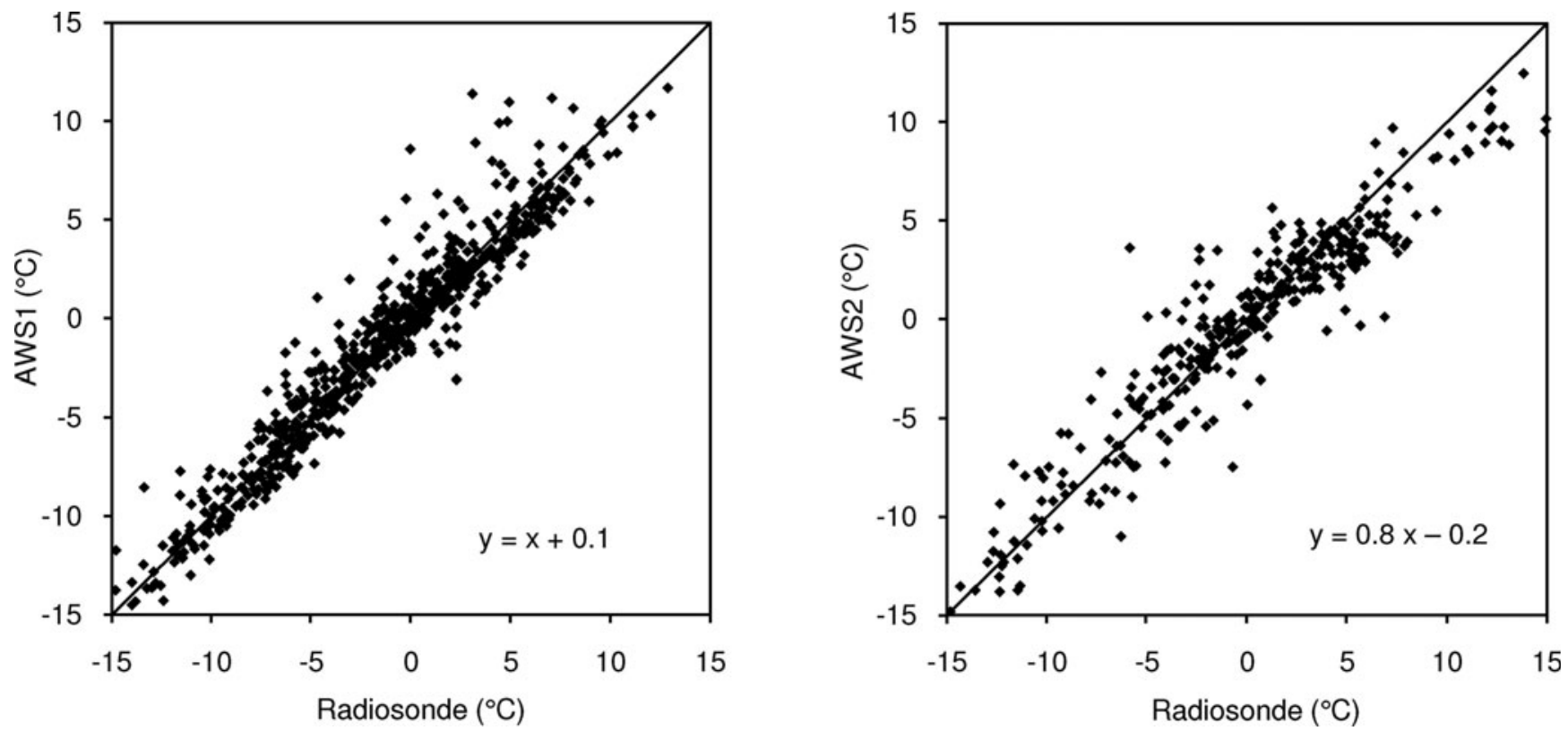

Fig. 13. Comparison of air temperature between AWSs and twice-daily radiosonde temperatures measured at the corresponding elevation of the AWSs. (a) AWS1 is 1 year of data from October 2007 to September 2008. (b) AWS2 is 6 months of data from April to September 2008 due to the later installation of this station. The line indicates $y=x$ and the equation indicates the best linear fit.

discrepancy between the radiosonde and AWS temperatures is the topography. Lower temperature measurements at the glacier than by the radiosonde are often connected with strong southerly winds. The direction of the glacier is from north to south and an explanation could be that orographic lifting of air along the glacier causes an adiabatic cooling that makes the air colder than the environment. Under specific meteorological conditions, measurement errors are a possible explanation for some of the observed discrepancy of the measured temperatures. Measured higher air temperatures at the glacier than by the radiosonde seem to coincide with low wind speed and high radiation conditions. In this case, some of the difference may arise due to heating of the radiation shields that cover the temperature sensors at the glacier due to the low wind speed and thus poor ventilation of the sensor (Klok and others, 2005).

\section{CONCLUSIONS}

Direct glaciological mass-balance measurements on Sørbreen show high spatial variability in the snow distribution due to uneven topography and wind-transported accumulation. The spatially inhomogeneous snow distribution leads to differential melt on the surface. The glacier-wide mass balance is therefore not calculated, but the measured point values are presented. The point measurements suggest constant melt rates at the interval from 330 to $570 \mathrm{~m}$ a.s.l., which may be due to the persistent temperature inversions. The effect of the temperature inversions on the ablation needs further investigation.

Calculated melt rate at the main weather station (330 ma.s.l.) is $3.6 \mathrm{~cm}$ w.e. $\mathrm{d}^{-1}$ for the snow-free period of 115 days from 8 June to 30 September 2008. The calculated melt rates agree well with measured melt rates. This suggests that the applied energy-balance model includes the main processes affecting the surface melt.

Net radiation is the highest contributor to the energy balance in the ice-melt season. The net shortwave radiation is the main contributor, while the net longwave radiation makes a generally negative contribution to the net radiation and the energy balance. However, the net radiation is the largest flux only in June-August. In September, the sensible heat flux is larger than the net radiation.

We found a high correlation, $R^{2}=0.96$ and 0.94 at 330 and $880 \mathrm{~m}$ a.s.l., respectively, between air temperatures at corresponding elevations measured by the AWSs and twicedaily radiosonde releases. We thus expect that radiosonde profiles will be valuable for deriving non-linear lapse rates for distributed melt models of Sørbreen.

\section{ACKNOWLEDGEMENTS}

The glacier mass-balance program on Jan Mayen was started by the Norwegian University of Life Sciences (UMB) in 2007. The project is supported by the Norwegian Research Council, the Svalbard Science Foundation and the Swedish Society for Anthropology and Geography. We thank Major S.L. Kroken (the Norwegian Defence Logistics Organization) and Å.L. Godø (Station Commander on Jan Mayen 2007-08) for logistic support to and on Jan Mayen, everyone who helped us carry equipment to the glacier and everyone who helped out with field measurements, and B. Denby, R. Hock, B. Brock and $\mathrm{H}$. Escher for helpful comments on, and reviews of, the manuscript.

\section{REFERENCES}

Anda, E., O. Orheim and J. Mangerud. 1985. Late Holocene glacier variations and climate at Jan Mayen. Polar Res., 3(2), 129-140.

Beljaars, A. and A. Holtslag. 1991. Flux parameterization overland surface for atmospheric models. J. Appl. Meteorol., 30(3), $327-341$.

Benestad, R.E. 2008. Empirical-statistical downscaled arctic temperature and precipitation series. Oslo, met.no. (Report 10/2008.)

Birkenmajer, K. 2004. Geology of Jan Mayen Island and surroundings. In Skreslet, S., ed. Jan Mayen Island in scientific focus. 
Dordrecht, etc., Kluwer Academic Publishers, 13-26. (NATO Science Series IV: Earth and Environmental Sciences.)

Førland, E.J., I. Hanssen-Bauer and P.Ø. Nordli. 1997. Climate statistics and long-term series of temperature and precipitation at Svalbard and Jan Mayen. Oslo, Det Norske Meteorologiske Institutt. (DNMI KLIMA Rapp. 21/97.)

Giesen, R.H., L.M. Andreassen, M.R. van den Broeke and J. Oerlemans. 2009. Comparison of the meteorology and surface energy balance at Storbreen and Midtdalsbreen, two glaciers in southern Norway. Cryosphere, 3(1), 57-74.

Hagen, J.O. 2004. The potential of the Beerenberg glaciers for climate studies. In Skreslet, S., ed. Jan Mayen Island in scientific focus. Dordrecht, etc., Kluwer Academic Publishers, 27-36. (NATO Science Series IV: Earth and Environmental Sciences.)

Hock, R. 2005. Glacier melt: a review on processes and their modelling. Progr. Phys. Geogr., 29(3), 362-391.

Hock, R. and B. Holmgren. 1996. Some aspects of energy balance and ablation of Storglaciären, northern Sweden. Geogr. Ann., 78A(2-3), 121-131.

Hov, Ø. 2004. Meteorological observations on Jan Mayen. In Skreslet, S., ed. Jan Mayen Island in scientific focus. Dordrecht, etc., Kluwer Academic Publishers, 37-40. (NATO Science Series IV: Earth and Environmental Sciences.)

Jonsell, U., R. Hock and B. Holmgren. 2003. Spatial and temporal variations in albedo on Storglaciären, Sweden. J. Glaciol., 49(164), 59-68.

Klok, E.J., M. Nolan and M.R. van den Broeke. 2005. Analysis of meteorological data and the surface energy balance of McCall Glacier, Alaska, USA. J. Glaciol., 51(174), 451-461.

Meehl, G.A. and 12 others. 2007. Global climate projections. In Solomon, S. and 7 others, eds. Climate change 2007: the physical science basis. Contribution of Working Group I to the Fourth Assessment Report of the Intergovernmental Panel on Climate Change. Cambridge, etc., Cambridge University Press, 747-845.

Munro, D.S. 1990. Comparison of melt energy computations and ablatometer measurements on melting ice and snow. Arct. Alp. Res., 22(2), 153-162.

Nakiáenoviá, N. and 27 others. 2000. Emissions scenarios: a special report of Working Group III of the Intergovernmental
Panel on Climate Change. Cambridge, etc., Cambridge University Press.

Nordli, P.Ø., I. Hanssen-Bauer and E.J. Førland. 1996. Homogeneity analyses of temperature and precipitation series from Svalbard and Jan Mayen. Oslo, Det Norske Meteorologiske Institutt. (DNMI Klima Rapp. 16/96.)

Oerlemans, J. 2000. Analysis of a 3 year meteorological record from the ablation zone of Morteratschgletscher, Switzerland: energy and mass balance. J. Glaciol., 46(155), 571-579.

Orheim, O. 1976. Bremålinger på Jan Mayen [Glaciological studies of Jan Mayen glaciers]. Nor. Polarinst. Årb. 1974, 249-252.

Orheim, O. 1993. Glaciers of Jan Mayen, Norway. In Williams, R.S., Jr and J.G. Ferrigno eds. Satellite image atlas of glaciers of the world. Denver, CO, US Geological Survey, E153-E164. (USGS Professional Paper 1386-E.)

Østrem, G. and M. Brugman. 1991. Glacier mass-balance measurements. A manual for field and office work. Saskatoon, Sask., Environment Canada. National Hydrology Research Institute. (NHRI Science Report 4.)

Rolstad, C. and J. Oerlemans. 2005. The residual method for determination of the turbulent exchange coefficient applied to automatic weather station data from Iceland, Switzerland and West Greenland. Ann. Glaciol., 42, 367-372.

Schneider, C., R. Kilian and M. Glaser. 2007. Energy balance in the ablation zone during the summer season at the Gran Campo Nevado Ice Cap in the Southern Andes. Global Planet. Change, 59(1-4), 175-188.

Sicart, J.E., P. Wagnon and P. Ribstein. 2005. Atmospheric controls of the heat balance of Zongo Glacier ( $16^{\circ} \mathrm{S}$, Bolivia). J. Geophys. Res., 110(D12), D12106. (10.1029/2004JD005732.)

Six, D., P. Wagnon, J.E. Sicart and C. Vincent. 2009. Meteorological controls on snow and ice ablation for two contrasting months on Glacier de Saint-Sorlin, France. Ann. Glaciol., 50(50), 66-72.

Trondsen, K. 2008. Estimating the mass balance of Sørbreen glacier from 1973-2008 using degree-day models. (MSc thesis, Norwegian University of Life Sciences.)

Wedøe Rødby, R. 2009. Comparison of air temperatures measured from radiosondes and automatic weather stations for 2007/2008 on Sørbreen, Jan Mayen. (MSc thesis, Norwegian University of Life Sciences.) 